\title{
INFLUENCE OF TOPOGRAPHIC AND HYDROGRAPHIC FACTORS ON THE SPATIAL DISTRIBUTION OF LEPTOSPIROSIS DISEASE IN SÃO PAULO COUNTY, BRAZIL: AN APPROACH USING GEOSPATIAL TECHNIQUES AND GIS ANALYSIS.
}

\author{
M.C. Ferreira ${ }^{\mathrm{a}, *}$, M.F.M. Ferreira ${ }^{\mathrm{b}}$ \\ ${ }^{a}$ Geosciences Institute, UNICAMP, State University of Campinas, Campinas - SP, Brazil - macferre@ige.unicamp.br \\ ${ }^{\mathrm{b}}$ Nature Sciences Institute, UNIFAL-MG, Alfenas - MG, Brazil-martafelicia@uol.com.br
}

Comission VIII, WG VIII/2

KEY WORDS: Spatial Analysis, GIS, Leptospirosis Disease, Sao Paulo, Brazil, Environmental Variables

\begin{abstract}
:
Leptospirosis is a zoonosis caused by Leptospira genus bacteria. Rodents, especially Rattus norvegicus, are the most frequent hosts of this microorganism in the cities. The human transmission occurs by contact with urine, blood or tissues of the rodent and contacting water or mud contaminated by rodent urine. Spatial patterns of concentration of leptospirosis are related to the multiple environmental and socioeconomic factors, like housing near flooding areas, domestic garbage disposal sites and high-density of peoples living in slums located near river channels. We used geospatial techniques and geographical information system (GIS) to analysing spatial relationship between the distribution of leptospirosis cases and distance from rivers, river density in the census sector and terrain slope factors, in Sao Paulo County, Brazil. To test this methodology we used a sample of 183 geocoded leptospirosis cases confirmed in 2007, ASTER GDEM2 data, hydrography and census sectors shapefiles. Our results showed that GIS and geospatial analysis techniques improved the mapping of the disease and permitted identify the spatial pattern of association between location of cases and spatial distribution of the environmental variables analyzed. This study showed also that leptospirosis cases might be more related to the census sectors located on higher river density areas and households situated at shorter distances from rivers. In the other hand, it was not possible to assert that slope terrain contributes significantly to the location of leptospirosis cases.
\end{abstract}

\section{INTRODUCTION}

Leptospirosis is a worldwide geographical distribution zoonosis, caused by Leptospira genus bacteria, affecting animals and humans. Rodents, especially the Rattus norvegicus, are the most important hosts of this microorganism (Caldas, 1979). The transmission to humans occurs by direct contact with urine, blood or tissues of the rodent, and indirectly, by contact with water or mud contaminated by urine of rodents. In tropical areas, leptospirosis epidemics occur in the wet and hot season, mainly after great flooding events.

Multiple geographical factors contributing to the human contact with bacteria and disease vectors, like slope terrain, land use, distance from rivers, sanitation conditions and socioeconomic level of population (Barcelos; Sabroza 2001; Reis, 2008; Soares et al., 2010; Robertson et al., 2012; Raghavan et al., 2012; Gracie et al., 2014; Vega-Corredor; Opadeyi, 2014). Outbreaks of leptospirosis in Brazil are concentrated between OctoberMarch months. In these rainiest and hottest months of year occurs large floods, expanding the spatial diffusion of Leptospira among the population that lives near water bodies or in frequently flooded terrain depressions.

In the first decade of $21^{\text {th }}$ century, Brazil had a relative economic growth that produced an increase in the salaries of poor families living in peripheral neighbourhoods of large cities. However, there are still serious public health and environmental sanitation problems, mainly in Sao Paulo, the most populous metropolitan area of the country, with 11.581,000 inhabitants (SEADE, 2015). Due high population density, elevated rate of poverty in some neighbourhoods and great quantity of people living in slums, these areas of the city are potentially epidemic for leptospirosis, mainly those located near flooding sites or urban river channels.

The objective of this study was to evaluate the use of geospatial techniques and GIS operations to determine how some environmental variables, like distance from rivers, river density in the census sector and terrain slope, influencing the spatial distribution of leptospirosis in Sao Paulo city, Brazil. In this study, we used a sample of 183 geocoded leptospirosis cases confirmed in 2007 as test. The geographical position of cases and the incidence by neighbourhood are shown in the Figure 1. The Figure 2 displays the kernel density map of cases using a $2,000 \mathrm{~m}$ radius.

\section{MATERIAL AND METHODS}

\subsection{Material}

a) Sao Paulo County boundaries map, hydrographic network map and census sectors database, in shapefile format, obtained from Metropolis Studies Centre of Sao Paulo (CEM, 2014)

b) ASTER-GDEM2 digital elevation model (DEM), in raster format, obtained from http://gdem.ersdac.jspacesystems.or.jp/

c) Shapefile in point format, containing 183 geocoded leptospirosis cases confirmed in Sao Paulo in 2007, obtained from Metropolis Studies Centre of Sao Paulo and Brazilian Health System database (CEM, 2014; SIH, 2007).

All the spatial data were projected in South American Datum 1969 (SAD69) and Universal Transverse of Mercator (UTM) 
coordinate system, using the map projection tool of QGIS 2.2.0 - Valmiera (GNU General Public License).

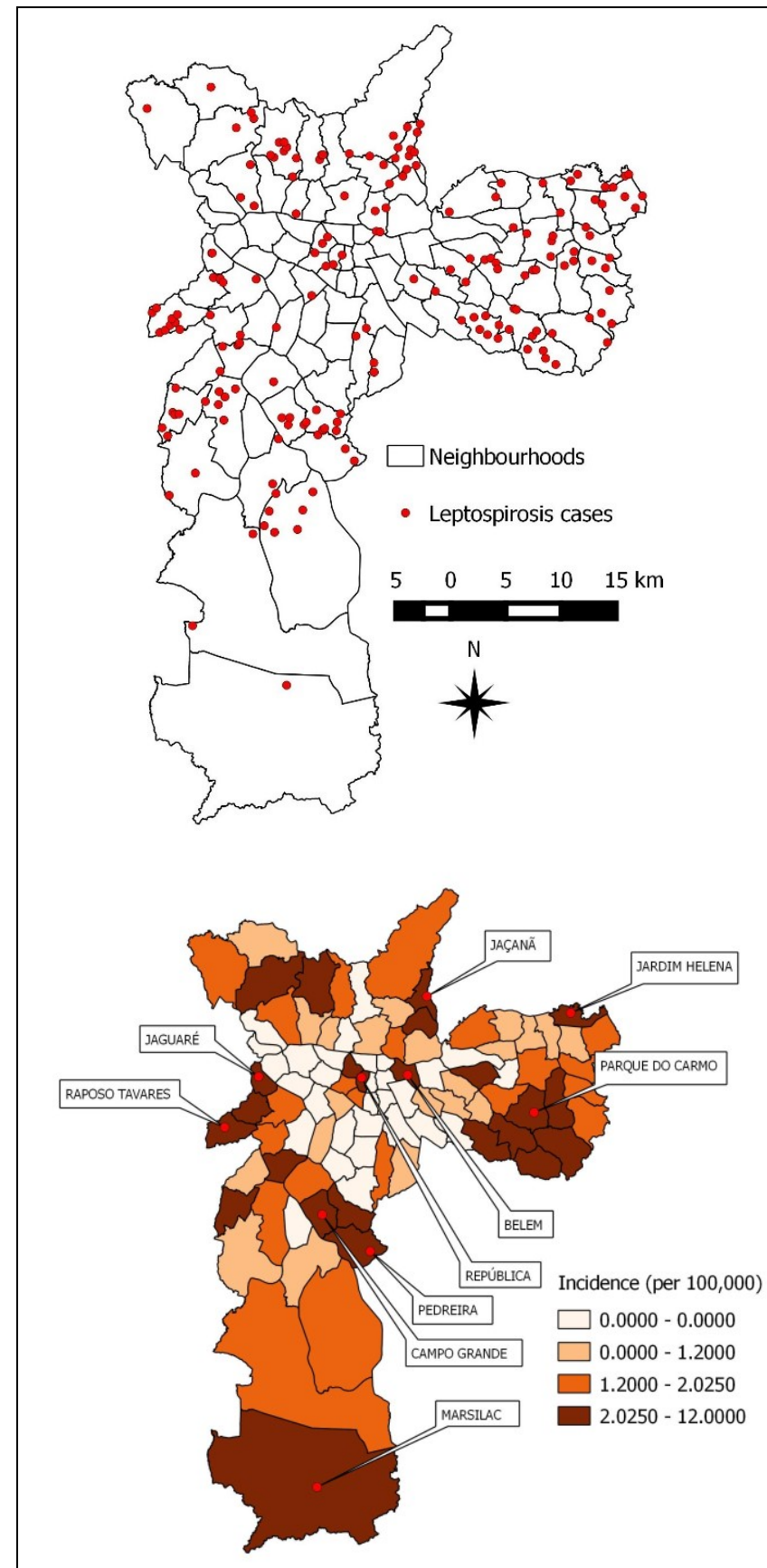

Figure 1 - Above: Map of the 183 leptospirosis cases confirmed in Sao Paulo municipality in 2007, used as test in this study. Below: Thematic map of incidence of cases by neighbourhood. The more infected neighbourhood are highlighted in box text.

\subsection{Methods}

\subsubsection{Distance from rivers}

To investigate the role of average distance from rivers (DISTRIV) on location of leptospirosis cases, buffer analysis operation using the hydrographic map was performed. Buffers with distances varying from 100 to 3,000 meters around rivers were generated using the Vector Analysis module of QGIS. The number of leptospirosis cases recorded in each $100 \mathrm{~m}$ river distance interval was calculated using Point-on-Polygons operator, available on Vector Analysis module of QGIS.

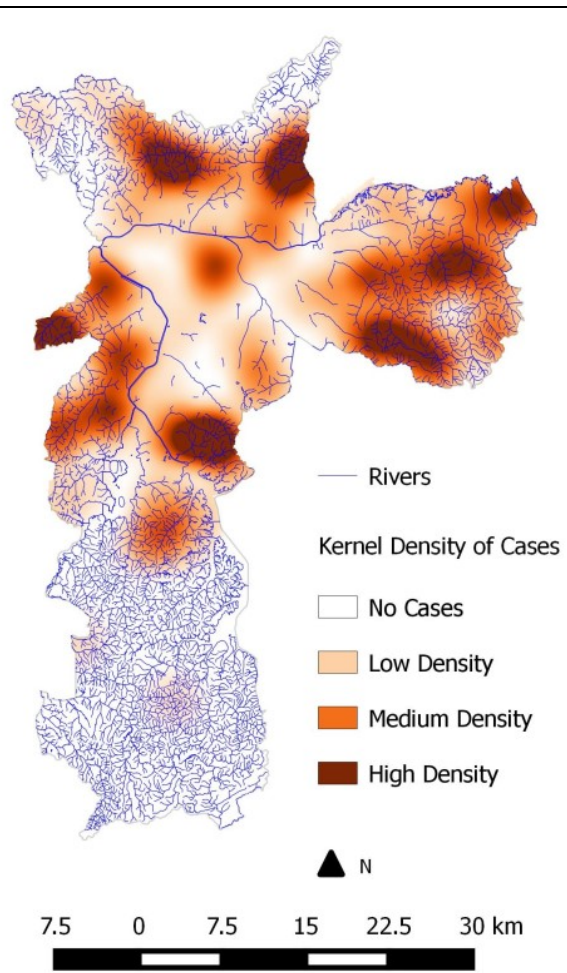

Figure 2 - Kernel density map of leptospirosis cases in Sao Paulo.

\subsubsection{River density}

River density in the census sector (RIVDEN) was mapped using hydrographic and census sector maps. Firstly, it was calculated the sum of river segments in each census sector polygon, using Vector Analysis module of QGIS. Then, river density was calculated using the field calculator tool, available on Attribute Table module of QGIS. RIVDEN values were mapped using a six-class legend: $0-20 \mathrm{~km} / \mathrm{km}^{2}, 20-40 \mathrm{~km} / \mathrm{km}^{2}, 40-60 \mathrm{~km} / \mathrm{km}^{2}$, $60-80 \mathrm{~km} / \mathrm{km}^{2}, 80-100 \mathrm{~km} / \mathrm{km}^{2}$ and $\geq 100 \mathrm{~km} / \mathrm{km}^{2}$.

\subsubsection{Slope terrain}

To evaluate the topographic effect on location of leptospirosis cases, we used the terrain slope variable (TERSLO), due its influence on the movement and storage of water during heavy rainfalls. ASTER GDEM2 digital elevation data were used to map the terrain slope using the Raster Terrain Analysis module of QGIS. The quantity and frequency of leptospirosis cases by slope class interval was obtained using the Point-on-Polygons operator of QGIS.

\subsubsection{Statistical analysis}

Kolmogorov-Smirnov test (KS) was used to evaluate the adherence between observed cumulative frequency and expected cumulative frequency of cases by DISTRIV, RIVDEN and TERSLO class intervals. The maximum $D$-values calculated for the differences between observed and expected cumulative frequencies were evaluated on its significance level $(\alpha)$, using the KS statistical table (Taylor, 1977). The $\alpha$-values were used to evaluate the relative influence of environmental variables on the spatial distribution of leptospirosis cases. 


\section{RESULTS AND DISCUSSION}

The frequency of leptospirosis cases in the class intervals of DISTRIV, RIVDEN and TERSLO variables are shown, respectively, in the Tables 1, 2 and 3. Examining the DISTRIV variable (Table 1) we noted that 77 of 183 cases occurred in households located in DISTRIV $\leq 100 \mathrm{~m}$ areas $\left(f_{r}=0.4208\right)$ and 129 of 183 cases $(77+52)$ occurred in DISTRIV $\leq 200 \mathrm{~m}$ areas $\left(f_{r}=0.7049\right)$. Mostly of cases were located nearby first and second orders river channels, distributed by the north, east, southwest and southeast regions of Sao Paulo County (Figure 3).

\begin{tabular}{|c|c|c|c|c|c|}
\hline $\begin{array}{c}\text { DISTRIV } \\
(\mathrm{m})\end{array}$ & $\begin{array}{c}\text { Density } \\
\left(\mathrm{km}^{-2}\right)\end{array}$ & $\mathrm{N}_{\mathrm{ob}}$ & $\mathrm{N}_{\mathrm{ex}}$ & $\mathrm{f}_{\mathrm{r}-\mathrm{ob}}$ & $\mathrm{f}_{\mathrm{r}-\mathrm{ex}}$ \\
\hline $0-100$ & 0.138 & 77 & 66.9 & 0.420 & 0.365 \\
\hline $100-200$ & 0.143 & 52 & 43.6 & 0.284 & 0.238 \\
\hline $200-300$ & 0.084 & 15 & 21.3 & 0.082 & 0.116 \\
\hline $300-400$ & 0.158 & 17 & 12.8 & 0.092 & 0.070 \\
\hline $400-500$ & 0.087 & 7 & 9.6 & 0.038 & 0.052 \\
\hline$>500$ & 0.063 & 15 & 28.6 & 0.082 & 0.156 \\
\hline Total & 0.120 & 183 & 183 & 1.000 & 1.000 \\
\hline
\end{tabular}

Table $1-$ Number of observed $\left(N_{o b}\right)$ and expected $\left(N_{\exp }\right)$ leptospirosis cases, their frequencies $\left(f_{r-o b}, f_{r-e x}\right)$ and density by distance from rivers interval, in Sao Paulo, 2007 ( $n=183$ cases).

\begin{tabular}{|c|c|c|c|c|c|}
\hline $\begin{array}{c}\text { RIVDEN } \\
\left(\mathrm{km} / \mathrm{km}^{2}\right)\end{array}$ & $\begin{array}{c}\text { Inc. } \\
(100,000)\end{array}$ & $\mathrm{N}_{\text {ob }}$ & $\mathrm{N}_{\exp }$ & $\mathrm{f}_{\mathrm{r}-\mathrm{ob}}$ & $\mathrm{f}_{\mathrm{r}-\mathrm{ex}}$ \\
\hline $0-20$ & 1.428 & 127 & 145.7 & 0.694 & 0.796 \\
\hline $20-40$ & 2.855 & 26 & 14.9 & 0.142 & 0.081 \\
\hline $40-60$ & 2.245 & 13 & 9.4 & 0.071 & 0.051 \\
\hline $60-80$ & 2.105 & 7 & 5.4 & 0.038 & 0.029 \\
\hline $80-100$ & 2.680 & 5 & 3.0 & 0.027 & 0.016 \\
\hline$>100$ & 0.761 & 2 & 4.3 & 0.010 & 0.023 \\
\hline Total & 1.639 & 183 & 183 & 1.000 & 1.000 \\
\hline
\end{tabular}

Table 2 - Number of observed $\left(N_{o b}\right)$ and expected $\left(N_{\text {exp }}\right)$ leptospirosis cases, their respective frequencies $\left(f_{r-o b}, f_{r-e x}\right)$ and incidence per 100,000 inhabitants (Inc) by river density in the census sector interval, in Sao Paulo, 2007 ( $\mathrm{n}=183$ cases).

\begin{tabular}{|c|c|c|c|c|c|}
\hline $\begin{array}{c}\text { TERSLO } \\
(\text { degrees })\end{array}$ & $\begin{array}{c}\text { Density } \\
\left(\mathrm{km}^{-2}\right)\end{array}$ & $\mathrm{N}_{\mathrm{ob}}$ & $\mathrm{N}_{\mathrm{ex}}$ & $\mathrm{f}_{\mathrm{r}-\mathrm{ob}}$ & $\mathrm{f}_{\mathrm{r}-\mathrm{ex}}$ \\
\hline $0-5$ & 0.125 & 70 & 60.3 & 0.382 & 0.330 \\
\hline $5-10$ & 0.107 & 69 & 69.3 & 0.377 & 0.379 \\
\hline $10-15$ & 0.115 & 35 & 32.8 & 0.191 & 0.179 \\
\hline $15-20$ & 0.076 & 9 & 12.6 & 0.049 & 0.069 \\
\hline $20-25$ & 0.000 & 0 & 4.8 & 0.000 & 0.026 \\
\hline$>25^{\circ}$ & 0.000 & 0 & 2.8 & 0.000 & 0.015 \\
\hline Total & 0.108 & 183 & 183 & 1.000 & 1.000 \\
\hline
\end{tabular}

Table 3 - Number of observed $\left(N_{o b}\right)$ and expected $\left(N_{\exp }\right)$ leptospirosis cases, their respective frequencies $\left(f_{r-o b}, f_{r-e x}\right)$ and density, by terrain slope interval, in Sao Paulo, 2007 ( $n=183$ cases).

In relation to the RIVDEN variable (Table 2), the results showed that the incidence of cases in census sectors located in lower river density areas (RIVDEN $\leq 20 \mathrm{~km} / \mathrm{km}^{2}$ ) was 1.428 per 100,000 . In the other hand, the incidence in census sectors located in higher river density areas $\left(80 \mathrm{~km} / \mathrm{km}^{2} \leq\right.$ RIVDEN $\leq$ $100 \mathrm{~km} / \mathrm{km}^{2}$ ) was 2.680 per 100,000 inhabitants.
The map of Figure 4 indicate that in RIVDEN $=0$ census sectors, situated predominantly in the central urban area, the frequency of cases was lower than in census sectors situated in bordering areas.

Preliminary statistical analysis of hydrographic variables, using KS test, showed that DISTRIV $\left(D_{\text {critical }}=0.1007\right)$ and RIVDEN $\left(D_{\text {critical }}=0.0958\right)$ were both statistically significant at $\alpha=0.05$ and $\alpha=0.10$, respectively, indicating that spatial distribution of leptospirosis may be influenced by spatial hydrographical factors.

Evaluating TERSLO variable (Table 3) we noted that in the smoothest areas of the city (TERSLO $\leq 5^{\circ}$ ) it were observed 70 of 183 cases $\left(f_{r}=0.3825\right)$, and 9 of 183 cases in the steepest areas $\left(T E R \_S L O \geq 15^{\circ}\right)\left(f_{r}=0.076\right)$.

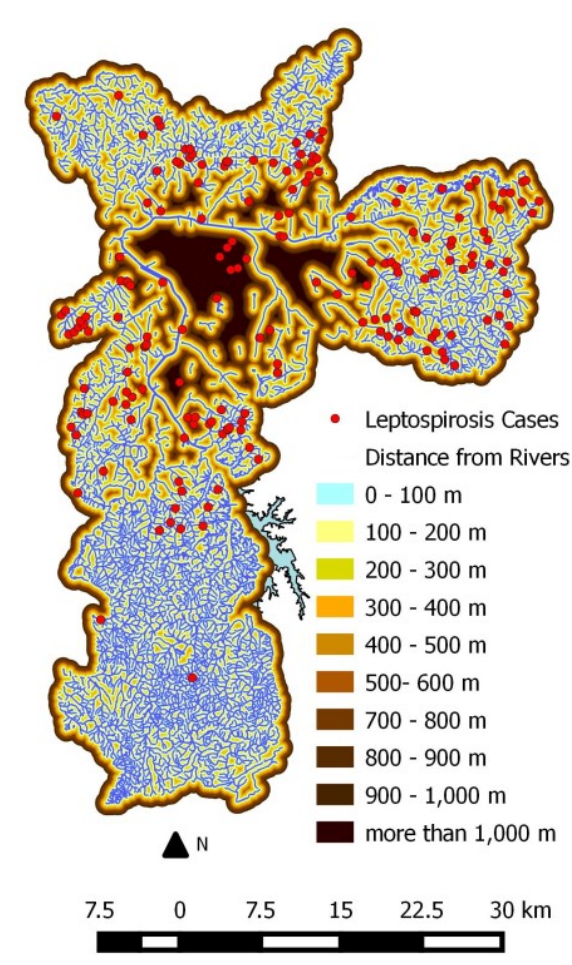

Figure 3 - Distribution of leptospirosis cases in relation to distance from rivers (DISTRIV) in Sao Paulo, Brazil.

The slope map of Figure 5 shows that the steepest areas in Sao Paulo are restricted principally to south and north borders of county. In those areas, population density and number of cases are both lower than other parts of county. It that map it is difficult to identify a clear association between slope classes and density of cases.

Based on the epidemiological data used in this study and in the KS test results obtained for TERSLO variable $\left(D_{\text {critical }}=0.0620\right.$, $\alpha>0.20$ ), is not possible to assert that this topographic factor contributed significantly to the location of leptospirosis cases.

Our preliminary results obtained for DISTRIV and RIVDEN variables corroborate results from other studies. Sunaryo (2012) concluded that leptospirosis is more frequent in households located at less than $300 \mathrm{~m}$ from rivers in Semarang City, Central Java. Robertson et al. (2012) noted that higher risk areas for 
leptospirosis in Sri Lanka are located at less than $400 \mathrm{~m}$ distance from rivers.

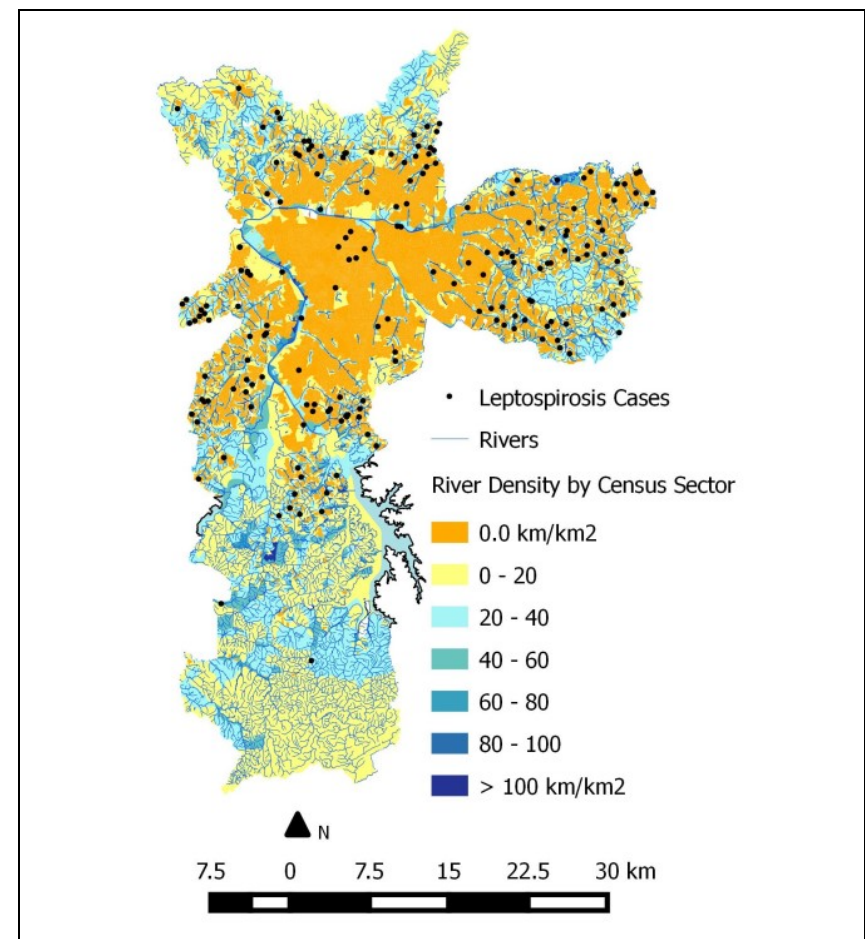

Figure 4 - Distribution of leptospirosis cases in relation to river density in the census sector (RIVDEN) in Sao Paulo, Brazil.

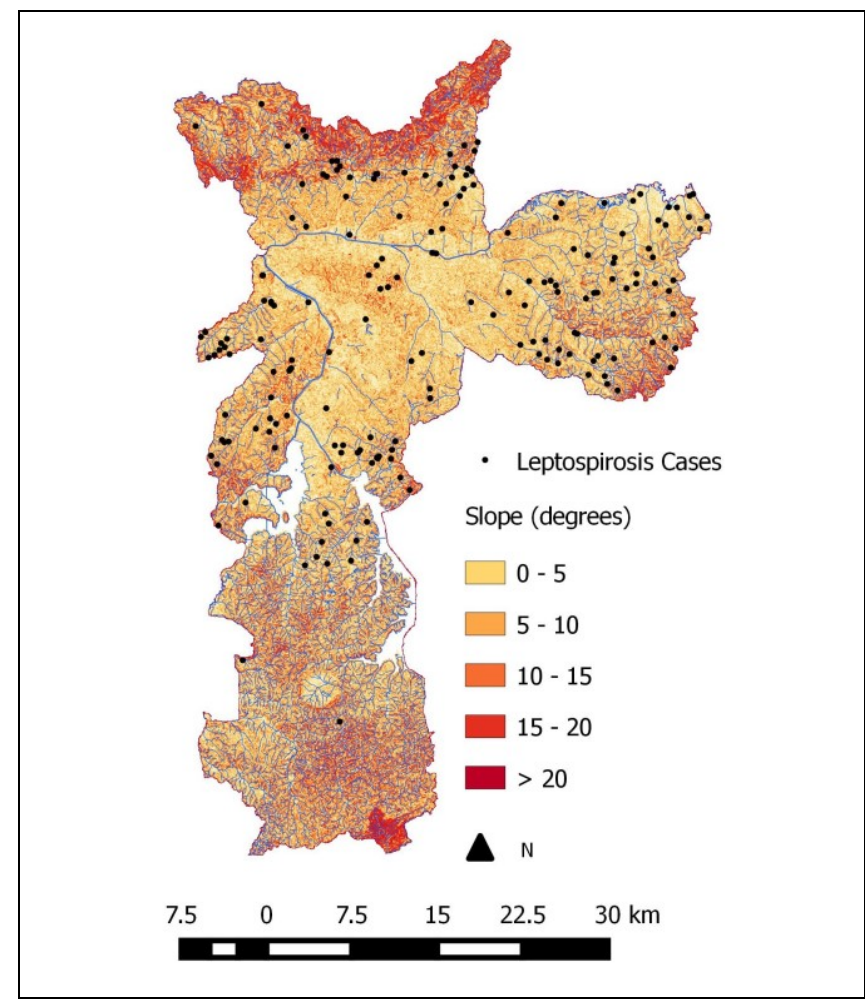

Figure 5 - Distribution of leptospirosis cases in relation to terrain slope (TERSLO) in Sao Paulo, Brazil.

\section{CONCLUSIONS}

Although our study was based on a small sample of cases, the results obtained for hydrological variables are in according to the literature. However, the consistence of these conclusions require further research based on higher quantity of geocoded cases. In spite of this, that sample was valuable to assess the GIS-based geospatial approach used in this research, and to understand better the geography of this disease in the urban scale.

The use of GIS and geospatial analysis techniques expanded the mapping resources applied to the integrated visualization of leptospirosis cases location and environmental variables. Moreover, the GIS-based approach permitted also identify and quantify the association between location of cases and spatial distribution of hydrographical and slope variables on the Sao Paulo municipality.

\section{ACKNOWLEDGEMENTS}

We thank to National Council for Scientific and Technological Development of Brazil (CNPq) for funding this research.

\section{REFERENCES}

ASTER GDEM. Global Digital Elevation Model version 2. http://gdem.ersdac.jspacesystems.or.jp/. Accessed in Oct. 6, 2014.

Barcellos, C.; Sabroza, E.P.C., 2001. The place behind the case: leptospirosis risks and associated environmental conditions in a flood related outbreak in Rio de Janeiro. Caderno de Saúde Pública, 17:59-67.

Caldas, E.M., 1979. Estudo epidemiológico de um surto de leptospirose na cidade de Salvador em maio de 1979. Revista do Instituto Adolfo Lutz, 39(1):35-94.

CEM. Centro de estudos da metrópole. http://www.fflch.usp.br/centrodametropole/

Gracie, R.; Barcellos, C.; Magalhães, M.; Souza-Santos, R. Barrocas, P.R.G., 2014. Geographical scale effects on the analysis of leptospirosis determinants. Int. J. Environ. Public Health, 11, 10366-10383, doi:10.3390/ijerph111010366.

QGIS 2.2. Quantum GIS v. 2.2.0 Valmiera. www.gnu.org/licenses.

Raghavan, R.K.; Brenner, K.M.; Higgins, J.J.; Hutchinson, J.M.S.; Harkin, K.R., 2012. Evaluations of hydrologic factors for canine leptospirosis: 94 cases (2002-2009). Preventive Veterinary Medicine, 107:105-109.

Reis, R.B.; Ribeiro, G.S.; Felzemburg, R.D.M.; Santana, F.S.; Mohr, S.; Melendez, A. et al., 2008. Impact of environment and social gradient on leptospira infection in urban slums. PLoS Negl. Trop. Dis., 2, doi:10.1371/jornal.pntd.0000228.

Robertson, C. Nelson, T.A.; Stephen, C., 2012. Spatial epidemiology of suspected clinical leptospirosis in Sri Lanka. Epidemiology Infectious, 140:731-743.

SEADE, 2015. Sistema estadual de análise de dados. Secretaria de Planejamento e Desenvolvimento Regional. Governo do Estado de São Paulo. http://www.seade.gov.br/. 
SIH, 2007. Sistema de Informação Hospitalar, SUS - Ministério da Saúde. CEPID-FAPESP/Centro de Estudos da Metrópole (CEM).

Soares, T.S.; Latorre, D.D.; Laporta, G.Z.; Buzzar, M.R., 2010. Spatial and seasonal analysis on leptospirosis in the municipality of Sao Paulo, southeastern Brazil, 1998 to 2006. Revista de Saúde Pública, 44:283-291.

Sunaryo, D.W., 2012. Mapping of leptospirosis risk factor based on remote sensing image in Tembalang, Semarang City, Central Java. Health Science Indonesian, 3 (1).

Taylor P.J., 1977. Quantitative methods in geography: an introduction to spatial analysis. Boston, Houghton Mifflin Co.

Tachikawa, T.; Kaku, M.; Iwasaki, A.; Gesch, D.; Oimoen, M., 2011. ASTER Global Digital Elevation Model version 2 summary of validation results. NASA Land Processes Distributed Active. Archive Center and the Joint Japan-US ASTER Science Team, Tokyo.

Vega-Corredor, M.C.; Opadeyi, J., 2014. Hydrology and public health: linking human leptospirosis and local hydrological dynamics in Trinidad, West Indies. Earth Perspectives, 1:3. 